\title{
Research on Customer Loyalty of Commercial Fitness Club based on Service Profit Chain
}

\author{
Yanlan Li \\ School of economics and management, Jiangsu University of Science and Technology, \\ Zhenjiang212000, China.
}

\begin{abstract}
With the rapid development of market economy, the competition of commercial fitness clubs is becoming more and fiercer. If commercial fitness clubs want to be in an advantageous position in the fierce market competition to occupy a large market share in the first place, they should focus on improving customer loyalty instead of blindly expanding the number of customers. In the course of the development of commercial fitness clubs, the phenomenon of one-time consumption often occurs, that is, after customers buy the products, there are many problems, which cannot be solved in time. As a result, customers no longer spend money on the club, however, the local population of the club is relatively fixed and the mobility is not large. After losing existing customers, the club's profits will be greatly reduced. A large number of data analysis shows that customer loyalty has a greater impact on the income of the club than the share of the club in the market.
\end{abstract}

Keywords: Commercial Fitness Club, service profit chain, customer loyalty, quality of service.

\section{Introduction}

With the rapid development of economy and the continuous improvement of people's living standard, people's fitness awareness has also been continuously enhanced. Commercial fitness clubs are springing up. Meanwhile, customers are increasingly demanding of the club. Market competition intensifies. If fitness clubs want to occupy an advantageous position in the fierce competition. They should set up the concept of customer-oriented, and put improving customer loyalty in the first place. However, when commercial fitness clubs blindly expand their Numbers, they neglect that competition is actually competition for customers. How to retain old members and maximize profits while absorbing new members becomes the best way to gain competitive advantage.

\section{The Meaning of Customer Loyalty}

According to the degree of customer loyalty, we divides it into three categories: behavior loyalty, loyalty and emotional loyalty; Behavioral loyalty refers to the repeated purchase of customers.; intention loyalty refers to the intention that customers may buy in the future; emotional loyalty refers to the attitude of the customers of the enterprise and the product, willing to promote the company's products to people around them. Combined with the above aspects, customer loyalty refers to: customers for a long time, have a preference for a particular enterprise and repeat purchase its product or service, is buying behavior and psychological dependence, and the buying behavior is sustainable.

\section{Service Profit Chain Model}

The service profit chain describes the relationship between the employee, the customer and the profit in the enterprise. That the theory of service profit chain: the ability of employees, employee satisfaction, employee loyalty, employee productivity, customer purchase and service value, customer satisfaction, customer loyalty, corporate profits have direct relationship. That is: The improvement of customer loyalty will promote the growth of enterprise profitability. Customer satisfaction determines customer loyalty, and customer satisfaction is determined by the value of the product or service obtained. Employees who are loyal to the company are in the role of creating products or services recognized by customers, and whether employees are loyal to their company depends on whether they are satisfied with the company. The high quality internal service provided by the enterprise determines the employee satisfaction [1].Two things need to be done to make this 
"chain" work. The first is to create the highest possible customer transfer value for its customers through external services, and the second is to create high "internal customer transfer value" for internal customers by providing high-quality internal services. The latter is more critical for services such as fitness clubs.

\section{Service Profit Chain Model of Fitness Club}

Commercial fitness club is for members to enhance physical fitness, entertainment, leisure, rehabilitation care, etc., and provide members with exercise site, advanced equipment, fixed equipment, yoga, swimming, exercise and other services of non-profit organizations. Take Lucky Bird Fitness Club for example: The staff of Lucky Bird fitness club can obtain high satisfaction and loyalty from the members by providing high-quality products and services to them. The satisfaction and loyalty of the members will bring huge benefits and rewards to the golden bird fitness club, Lucky Bird fitness club has a rich material basis for continuous development and expansion, the introduction of foreign advanced equipment and fitness concepts, which can create better conditions for the club, get the club staff greater satisfaction, make the club better service employees, eventually forming a virtuous circle of closed chain. According to the theory of service profit chain, we can get the model of service profit chain of Lucky Bird fitness club (see Figure 3).

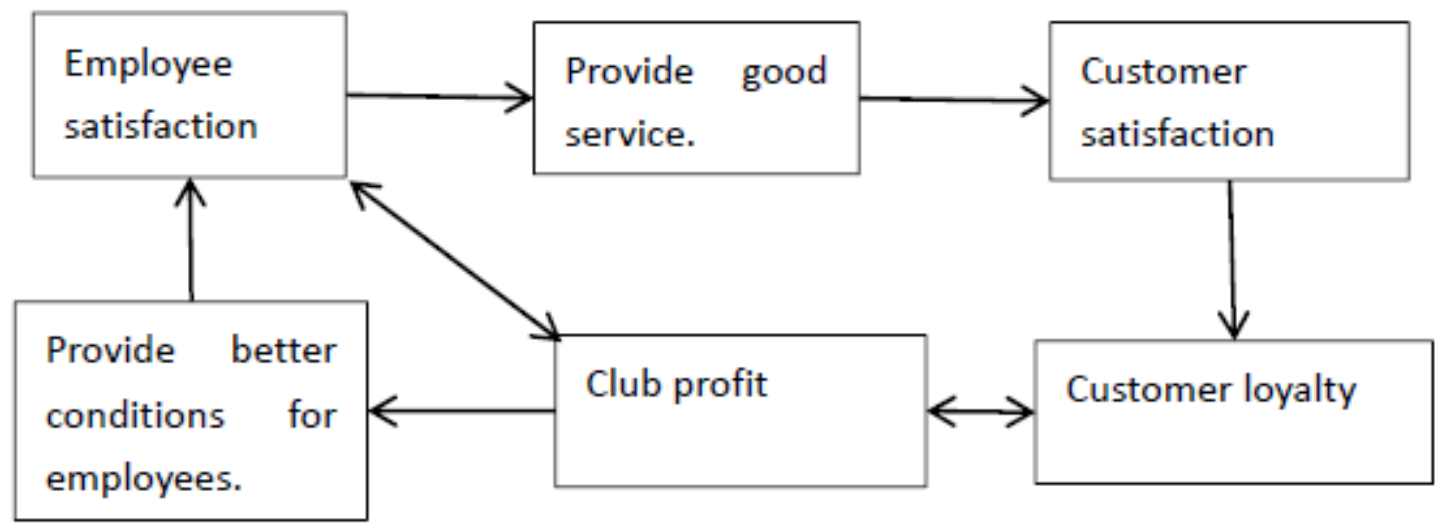

Figure 1. Lucky bird fitness club service profit chain model.

\section{The Value of Lucky Bird Fitness Club Service Profit Chain}

"The service profit chain model of Lucky Bird explains the relationship between club profitability, customer satisfaction and loyalty, employee satisfaction and loyalty, always implement the" member oriented "and" profit oriented "concept, to improve the fitness club inspired ginger Bird Club profits through the internal system of efficient management, the development of club management view from a new perspective [2]. "Lucky bird fitness club in the service profit chain to improve profitability, to continue to develop and retain profits is the key member of the club loyalty, loyalty membership has a lifetime value and increment value: firstly, loyal members will continue to renew, to guarantee the sustainable profits of the club; secondly, loyal members will not only consume other products and services in club, but also to bring people around to buy private lessons, to help promote the image of the club and services, establish a good reputation, so that more people join the club, the club's income will be significantly improved. Then, a new round of efforts to improve the satisfaction, loyalty and retention of new members will continue to develop, making the service profit chain in a virtuous circle and creating wealth for clubs continuously.

\subsection{Enhancing Employee Satisfaction to Provide Satisfactory Service}

According to the service profit linkage model, employee satisfaction and staff members are closely related to the service and attitude provided by their employees. The satisfaction of employees directly affects the behavior of employees in the work. Only when Lucky Bird fitness club employees are 
satisfied with their work and living conditions, will have a good mental state, to the club staff to provide good service, so Lucky Bird fitness club should pay attention to improve the club staff satisfaction through different ways [3].

\subsection{To Provide Better Service Can Improve Member Loyalty}

High quality service "the Lucky Bird fitness club staff members provide and promote member satisfaction, improve member loyalty, and ultimately improve the club's profits. Therefore, there is close relationship between direct satisfaction and loyalty of staff members, when the club staff carefully and diligently work, high quality service staff of the club has been recognized by customers, plastic, leisure and entertainment needs are met, in order to further improve customer satisfaction and loyalty to the enterprise.

\subsection{Customer Loyalty Won A Stable Income for Lucky Bird.}

Customer loyalty is an important source to increase Lucky Bird fitness club profit. Loyal customers will continue to buy the product or service in the club (continued to buy cards, private lessons etc.); and sponsors tend to have a lot of sponsorship of customer loyalty club, the fitness club will give decent income; only members of the trust and rely on, in order to ensure the continued profitability of the club [4].

\subsection{Continue to Provide Better Conditions for the Profit of Employees}

Only when the development state of ginger bird fitness club, the club will have sufficient funds to improve employee satisfaction, establish a good incentive mechanism, for employees to provide better working conditions and salary etc. Effective work motivation mechanism, humanized working environment, generous employee benefits, perfect medical and health services and other factors will largely stimulate club employees' enthusiasm for work, improve their work enthusiasm and enhance their satisfaction [5].

\section{Lucky Bird Fitness Club to Improve Member Loyalty Strategy}

\subsection{The Meaning of Improve the Lucky Bird Fitness Club Member Satisfaction}

The development of Lucky Bird fitness club depends on the loyalty of employees and members of the club, the most valuable is that some people have become a member, because once they improve their loyalty, they will continue to consume or say the products and services provided to, a lot of interest, so loyal members is fundamental to the club sustainable development. The premise of fitness club loyalty with ginger bird is the club can make the employee satisfaction, but members of a trade union to provide good services to its members, so as to improve employee satisfaction and loyalty to the club [6]. Because the member loyalty plays a very important role in the development of the club, so Lucky Bird fitness club should pay full attention to improve member loyalty. According to the theory of service profit chain, we should first improve employee satisfaction, and employees will provide quality products and services, so as to get highly recognized members, then satisfaction and loyalty will be raised, which will bring huge rewards to clubs. Have the following suggestions on the development of ginger bird fitness club.

\subsection{Effective Methods to Improve the Lucky Bird Fitness Club Member Satisfaction}

(1) It is an effective strategy for the club to improve the quality of the product and service, to meet the needs of the members, and to improve the satisfaction of the members. But to improve customer satisfaction requires a gradual process, in the initial stage, the company should adopt a unique and special brand image, attract the attention of potential customers, and through membership visit enterprises, to leave a good impression on the membership worth; to strengthen the stage, companies to take advantage of the members of the company have the impression, with the help of service, emotional marketing on the expression of customer care and attention, make the greatest efforts to 
meet the needs of members, members of which the firm purchase commitment; in the consolidation stage, enterprises in the foundation of emotional brand, continue to provide quality products and services to its members, to strengthen the members of the club's satisfaction in practice[7]; finally when the customer complaints and complaints, and to timely solve the compensation, in order to regain membership satisfaction.

(2)The relationship between the club and the members has been realized by the customer relationship management. CRM can benefit not only the members but also the club. A good CRM system can not only make the club better maintain existing customers, but also enable the club to find out the lost customers. The resource value management of customers is the core of CRM system. By constantly meeting the needs of customers, we can enhance customer loyalty and enhance profitability and competitiveness of enterprises. Commercial fitness clubs should formulate reasonable CRM management objectives based on their own characteristics, understand customer's consumption behavior, establish perfect customer files, and focus on the concept construction of CRM. The interactive relationship between the essence of customer relationship management to strengthen the club with customers, including through the establishment of a customer support, interaction, early warning and emergency response platform, information management system to realize the centralized management, so that the ginger bird fitness club can accurately grasp the palm dynamic customer demand, better to meet customer needs and create favorable the conditions [8].

(3) It is an effective way to improve customer loyalty by improving customer's conversion cost. Construction of enterprise switching barrier, allowing customers to change brands and suppliers make the conversion cost is too high to feel, or customers obtained in the original club interests will be lost because of the provision of such convertible brands, for a fitness club before the club cannot participate in promotions, it can enhance customer loyalty effectively. Establishing a close bond between the club and customers, making some promises that customers will take a long time to make, can also improve customers' transfer costs to other brands and enhance customer loyalty.

(4) The employee care and service to every customer, to create value for customers. Customer satisfaction is often determined by the perception that the customer compares the perceived effect of its product or service to the expected value. If a customer is satisfied with the product and service of an enterprise, he will spontaneously repeat or recommend the person around him to purchase the product, and loyalty to the product or service will continue to improve after experiencing many satisfactorily[9]. Therefore, the degree of customer satisfaction determines its loyalty to the company. We should strengthen the communication between club staff and members, organize various activities to let employees enter the inner world of customers, draw close distance between employees and customers, and set up a good image of club employees in customers.

\section{Summary}

From the perspective of service profit chain, to find out the influencing factors of customer loyalty, and then take targeted measures to improve customer satisfaction and loyalty, and promote long-term healthy development of the fitness club. On the basis of reading a lot of literature, from the perspective of service profit chain, this study explores the issue of improving customer loyalty in business fitness clubs, and puts forward feasible suggestions, which has important theoretical and practical significance. This paper studies the strategy of improving customer loyalty from the perspective of business fitness club service profit chain, hoping to give some suggestions for the development of business fitness clubs in China.

\section{References}

[1]. Service management and marketing in service competition. An empirical study from China [J]. Electronic Markets, 2012, 22 (2):73-82.

[2]. Anticipated Regret, Behavioural Decision Making. Seidenberg M. Journal [J]. International Journal of Information Management, 2015, 35 (6): 679-690. 
[3]. Wang Han. Satisfaction and customer loyalty service enterprise relationship M. Beijing: University press, 2013, (19): 23-26.

[4]. Study on the influence of fitness club service quality on customer loyalty of [J]. Sports science, 2014, 31 (15): 15-29.

[5]. Regret: A model of its antecedents and consequences in consumer decision making. Journal of Consumer Research [J]. Journal of Applied Psychology, 2011, 92(2): 227-293.

[6]. Putting the Service-Profit Chain to Work. James L, Thomas O Jones, Harvard Business. [J]. Research Policy, 2015, 44(8):1419-1430.

[7]. Customer loyalty: Toward an integrated conceptual framework [J]. Alan S. Dick. Journal of the Academy of Marketing Science, 1994, 25 (2):344-363.

[8]. Fitness club customer loyalty research D. Dalian University press, 2016, 37 (2): 21-29.

[9]. Harvard machine. The theory of service profit chain and its hidden meanings of [J]. Journal of Beijing Technology and Business University, 2016, 37 (2): 21-29. 